\title{
Lichen as indicator of metal pollution in the vicinity of SIPCOT industries in Cuddalore, southeast coast of India
}

\author{
Logesh $\mathrm{AR}^{1,2 \& 3}$, Upadhyay $\mathrm{AK}^{4}$, Joshi $\mathrm{S}^{3}$, Kalaiselvam $\mathrm{M}^{2}$, Upreti $\mathrm{DK}^{3}$, Shukla \\ $\mathrm{AC}^{1}$
}

${ }^{1}$ Department of Horticulture Aromatic \& Medicinal Plants, School of Earth Sciences \& Natural Resource Management, Mizoram University, Tanhril, Aizawl-796009, Mizoram, India

${ }^{2}$ Mycology Laboratory, Centre of Advanced Study in Marine Biology, Faculty of Marine Sciences, Annamalai University, Porto Novo-608502, Tamil Nadu, India.

${ }^{3}$ Lichenology Laboratory, Plant Diversity Systematics and Herbarium Division, CSIR-National Botanical Research Institute, Rana Pratap Marg, Lucknow-226001, Uttar Pradesh, India.

${ }^{4}$ Plant Ecology and Environmental Science Laboratory, CSIR-National Botanical Research Institute, Rana Pratap Marg, Lucknow - 226001, Uttar Pradesh, India.

Logesh AR, Upadhyay AK, Joshi S, Kalaiselvam M, Upreti DK, Shukla AC. 2014 - Lichen as indicator of metal pollution in the vicinity of SIPCOT industries in Cuddalore, southeast coast of India. Mycosphere 5(5), 681-688, Doi 10.5943/mycosphere/5/5/9

\begin{abstract}
Lichens are useful biological indicators of environmental contamination for a variety of metals and radionuclide of both natural and artificial origin. In present study, an active biomonitoring study was carried out with a commonly growing foliose species of Dirinaria applanata (Fée) D.D. Awasthi, collected from Pichavaram mangroves of Tamil Nadu. A total of twelve metal ( $\mathrm{Al}, \mathrm{Cd}, \mathrm{Cr}, \mathrm{Co}, \mathrm{Cu}, \mathrm{Fe}, \mathrm{Hg}, \mathrm{Mg}, \mathrm{Mn}, \mathrm{Ni}, \mathrm{Pb}$ and $\mathrm{Zn}$ ) accumulated in the transplanted lichen thalli of Dirinaria applanata at four sites (Parangipettai, SIPCOT, Cuddalore OT and NT) were targeted. The transplantation site near SIPCOT, being an industrial area exhibited highest concentration of $\mathrm{Al}, \mathrm{Cd}, \mathrm{Co}, \mathrm{Cu}, \mathrm{Fe}, \mathrm{Hg}, \mathrm{Mg}$ and $\mathrm{Mn}$ than the other sites. $\mathrm{Cr}(1009.98 \pm \mu \mathrm{g} / \mathrm{g} \mathrm{dw})$ and $\mathrm{Ni}(7.35 \pm \mu \mathrm{g} / \mathrm{g} \mathrm{dw})$ were found to be more at Cuddalore OT having higher anthropogenic activities while $\mathrm{Pb}$ and $\mathrm{Zn}$ were recorded maximum at Cuddalore NT with more vehicular activity. The level of most of the metals reached above the EPA standard. The accumulation of metals in different transplanted sites clearly indicates a particular type of metal accumulation with an anthropogenic activity in that area.
\end{abstract}

Key words - Dirinaria applanata - heavy Metal - monitoring Transplantation

\section{Introduction}

Lichens are being used as bioindicators since the mid half of twentieth century and quite a number of studies have been carried throughout the world (Brodo 1961, Le Blanc \& Rao 1973, Upreti \& Pandey 1994, 2000). In India, accounts of lichen biomonitoring studies with lichens are initiated in the last decade and detailed studies on both organic and inorganic metals are available from few regions of the country (Bajpai et al. 2004, 2009, 2010, 2010a, 2010b, Bajpai \& Upreti 2012, Saxena et al. 2007, Shukla \& Upreti 2007, 2011, Shukla et al. 2010). Few passive monitoring studies with lichens in Southern Indian region are available (Nayaka et al. 2003); however, no records of active monitoring in the area are so far available. Thus, in the present investigation, an attempt have been 
made to assess the status of metal pollution in and around industrial and traffic rich areas in Coastal Cuddalore district, with the help of a foliose lichen; which grows abundantly in mangroves.

Active monitoring employs the transplantation of lichens from healthy site to polluted site, for determining the level of pollution or accumulation. However, passive monitoring is a method where lichens are directly collected from the study sites to analyze the level of bioaccumulation. Since, the transplanted sites are mostly devoid of foliose lichen, as only few crustose forms were recorded on avenue trees, therefore the foliose lichens was used for the current investigation.

Literature reveals that among the different lichen species; members of lichen family Physciaceae (Pyxine sp., Dirinaria sp., Phaeophyscia sp.) were used frequently for biomonitoring (Bajpai et al. 2004, Shukla \& Upreti 2007, Satya et al. 2009, Bajpai et al. 2010a, 2011); therefore, in the present study, we have also used Dirinaria applanata for transplantation.

\section{Materials \& Methods}

\section{Study Area}

The study area, Pichavaram mangroves (coordinates between $11^{\circ} 23^{\prime} \mathrm{N}$ to $11^{\circ} 30^{\prime} \mathrm{N}$ latitude and $79^{\circ} 45^{\prime} \mathrm{E}$ to $79^{\circ} 50^{\prime} \mathrm{E}$ longitude) is situated $15 \mathrm{~km}$ northeast to Chidambaram, Cuddalore district of Tamil Nadu in South India.

The mangrove covers the area of about 1100 ha of which $50 \%$ is covered with forest, $40 \%$ by waterways and the remaining filled by sand-flats and mud-flats. It is an estuarine type mangrove biotope, located at the Vellar-Coleroon estuarine complex.

The fresh lichens were collected along with the substrate to prevent the damage of the thallus. Further, the collected lichen specimens were identified and authenticated following Awasthi (2007) and Singh \& Sinha (2010).

\section{Transplantation}

The lichen thalli were fixed on the hardboard with the help of glue along with the substratum. The boards containing lichen thalli were tied on building and trees at 5 meters and 10 meters height, respectively. The lichens were transplanted in 4 different sites right from Parangipettai (Site 1), SIPCOT (Site 2), Cuddalore OT (Site 3), and Cuddalore NT (Site 4) (Fig. 1, Table 1).

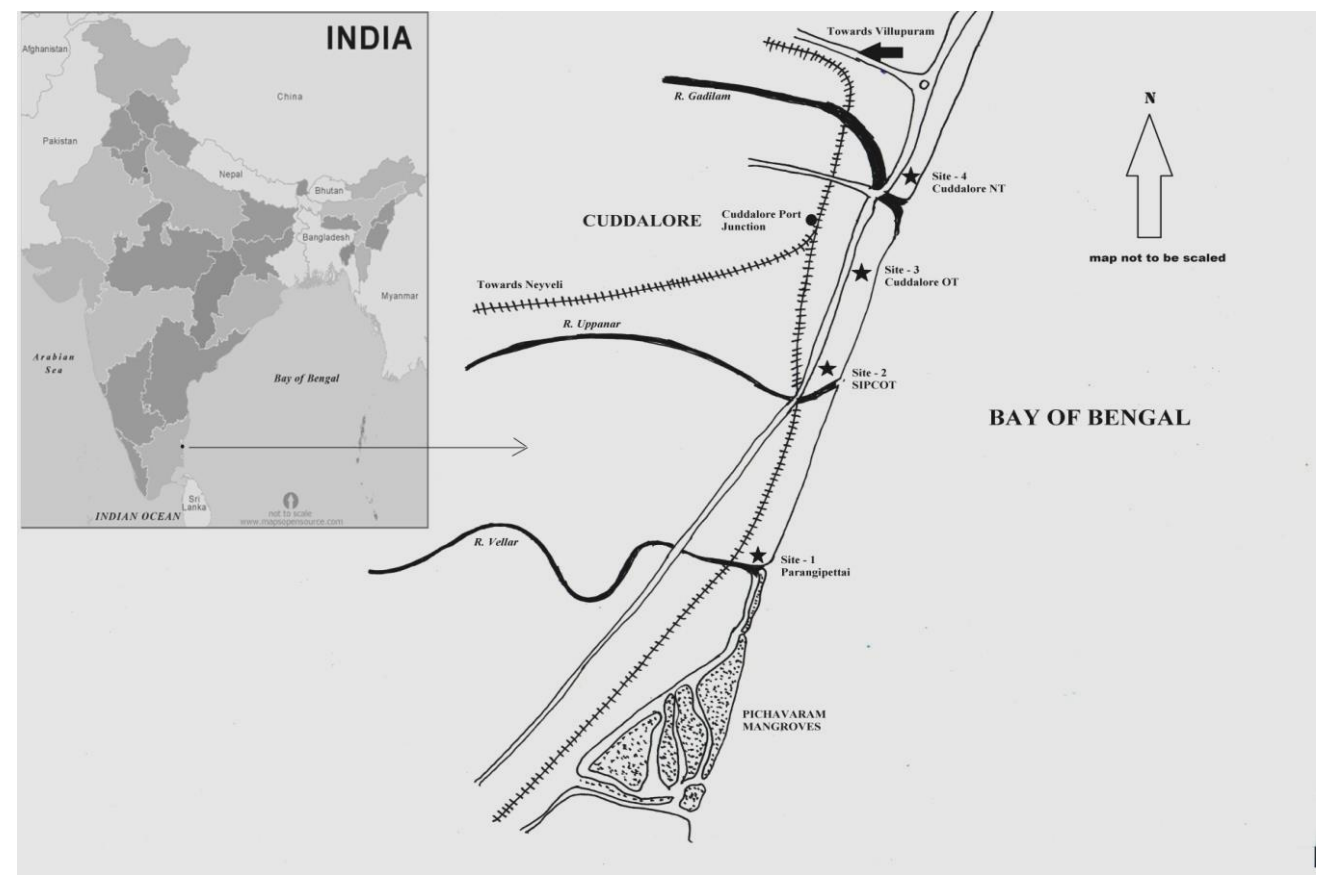

Fig. 1 - Transplanted sites 
Table 1 Description of the sites where the experiment conducted

\begin{tabular}{llll}
\hline Site & Locations & $\begin{array}{c}\text { Site Description } \\
\text { Height from ground }\end{array}$ & Remarks \\
\hline Site 1 & Parangipettai & $5 \mathrm{mts}$ & $\begin{array}{l}\text { Residential area } \\
\text { Purely industrial area } \\
\text { Site } 2\end{array}$ \\
SIPCOT Industrial estate & $5 \mathrm{mts}$ & $\begin{array}{l}\text { with } 53 \text { small industries } \\
\text { Area with traffic and } \\
\text { more }\end{array}$ \\
Site 3 & Cuddalore Old Town & $5 \mathrm{mts}$ & $\begin{array}{l}\text { activities } \\
\text { Area with more traffic } \\
\text { than site-3 }\end{array}$ \\
\hline
\end{tabular}

mts $=$ meters

\section{Heavy metal analysis}

The transplanted lichen thalli were exposed for 30 days. After 30 days, the lichen boards were collected and lichen thalli were cleaned, oven-dried for $24 \mathrm{~h}$ at $60^{\circ} \mathrm{C}$ temperature. The dried lichen samples were ground to powder; $0.5 \mathrm{~g}$ of sample was digested in a mixture of $\mathrm{HNO}_{3} / \mathrm{HClO}_{4}$ ( $v / v$ 9:1). Residues were filtered through Whatmann filter paper no. 42 and diluted to $20 \mathrm{~mL}$ with double-distilled water. Heavy metals in lichens, were determined by the method of Walting \& Walting (1982), and subsequently quantified by Inductively Coupled Plasma - Optical Emission Spectrophotometer (ICP-OES) (Perkin Elmer, USA).

\section{Statistical analysis}

The experiment was carried out in triplicates. The standard deviation in each case was, $\mathrm{n}=3$. Further, to confirm the validity and significance of the data, an analysis of variance (ANOVA< 0.01) was also performed.

\section{Results and Discussion}

The level of accumulation of heavy metals from the study sites were illustrated in Fig 1. Among the four different areas studied, site-1 was residential area, site- 2 was industrial area, site- 3 and site- 4 were the areas of heavy traffic and exposed for commercial exploitation. The lichens collected from the Pichavaram mangroves were initially estimated for the accumulation of heavy metals and observed that it was below the threshold level (Table 2).

After the transplantation of 30 days, it was observed that accumulations of heavy metals were increased in all the four sites in comparison to first day of transplantation (Table 3 \& Fig. 2). Lichen transplant laid at site-2, SIPCOT, an industrial area of Cuddalore; exhibit higher accumulation of all the metals ( $\mathrm{Al}, \mathrm{Cd}, \mathrm{Cr}, \mathrm{Cu}, \mathrm{Fe}, \mathrm{Hg}, \mathrm{Mg}$ and $\mathrm{Mn}$ ) except $\mathrm{Co}, \mathrm{Ni}, \mathrm{Pb}$ and $\mathrm{Zn}$. The probable reason for higher concentration of different metals in the area may be due to the presence of cluster of industries;plastic, fertilizer and aluminium manufacturing. The similar findings have already been reported by Dubey et al. (1999), Upreti \& Bajpai (2001), Bajpai et al. (2010a).

Aluminium ( $\mathrm{Al})$ is the third most abundant element found on the earth's crust (Lide 2005). Moreover, in the present investigation, accumulation of aluminium was higher at site 2 $\left(443.2 \pm 12.85 \mu \mathrm{g} \mathrm{g}^{-1}\right)$ followed by site $1\left(239.45 \pm 21 \mu \mathrm{g} \mathrm{g}^{-1}\right)$. The main anthropogenic emission of aluminium was reported by weathering of rocks, industrial process such as aluminium manufacturing and air emission (Lantzy \& MacKenzie 1979). Since, aluminium is not that much harmful to living beings, therefore the effect and accumulation of aluminium was least concerned. Cadmium is one of the most hazardous elements and it released into the environment by fossil fuel combustion, production of phosphate fertilizers and municipal solid waste incineration (Morrow 2010). Further, Rani et al. (2011) reported that Phaeophyscia hispidula accumulates Cadmium (Cd) ranging from $532 \mu \mathrm{g} \mathrm{g}^{-1}$ to $875 \mu \mathrm{g} \mathrm{g}$. . However, in the present investigation (Dirinaria applanata), Cadmium level was recorded higher at site $2\left(17.74 \pm 1.64 \mu \mathrm{g} \mathrm{g}^{-1}\right)$ followed by site 4 $\left(11.2 \pm 1.26 \mu \mathrm{g} \mathrm{g}^{-1}\right)$. 
Table 2 Heavy metal concentration in the thalli of lichen $D$. applanata collected from unpolluted site of Pichavaram Mangroves, Tamil nadu, India. All Values are mean \pm S.D. $(n=3)$

\begin{tabular}{ll}
\hline Metal & Accumulation $\left(\mu \mathbf{g ~ g}^{-1} \mathbf{d w}\right)$ \\
\hline Cadmium & N.D. \\
Copper & N.D. \\
Lead & N.D. \\
Nickel & $0.0033 \pm .0002$ \\
Mercury & $0.003 \pm .0001$ \\
Manganese & $0.396 \pm 0.06$ \\
Zinc & $1.08 \pm 0.076$ \\
Chromium & $5.83 \pm 0.31$ \\
Cobalt & $10.13 \pm 0.52$ \\
Aluminum & $9.06 \pm 1.89$ \\
Magnesium & $20.72 \pm 0.34$ \\
Iron & $106.01 \pm 0.172$ \\
\hline
\end{tabular}

The presence of Chromium ( $\mathrm{Cr}$ ) in lichen thallus exhibits its airborne origin, and it is emitted in the atmosphere by different sources like coal and oil combustion, steel manufacturing and cement production (Schutte 1977, Shtiza et al. 2008).

In the present investigation, concentration of $\mathrm{Cr}$ and Nickel (Ni) was ranging from $5.83 \pm 0.31$ to $1009.89 \pm 87.64 \mu \mathrm{g} \mathrm{g}^{-1} \mathrm{dw}$ and $0.003 \pm 0.0001$ to $7.36 \pm 0.87 \mu \mathrm{g} \mathrm{g}^{-1} \mathrm{dw}$, respectively, at site 3 ; the commercial area having railway junction, harbor and fishing industries. Chromium level was found higher at site-3 $\left(1009.89 \pm 12 \mu \mathrm{g} \mathrm{g}^{-1}\right)$ followed by site $2\left(979.92 \pm 14.56 \mathrm{gg} \mathrm{g}^{-1}\right)$. Similarly, literature also reveals that Dirinaria consimilis accumulated 61.80-1920 $\mu \mathrm{g} \mathrm{g}^{-1}$ and Phaeophyscia hispidula accumulated 103.79-1189.56 $\mu \mathrm{g} \mathrm{g}^{-1}$ of chromium (Mishra et al. 2003, Bajpai et al. 2004).

As per the literature, Lead $(\mathrm{Pb})$ content with traffic volume is directly proportional to $\mathrm{Pb}$ accumulation in lichen thallus (Takala \& Okkonen 1981). Phaeophyscia hispidula accumulates higher amount of $\mathrm{Pb}$ ranging from $8600 \pm 395$ to $12433 \pm 185 \mu \mathrm{g} \mathrm{g}^{-1}$ (Rani et al. 2011). However, the tyre activity and application of brake pads release Zinc (Zn) in the environment (Bajpai et al. 2011). Further, it was also reported that Phaeophyscia hispidula and Pyxine cocoes accumulates higher concentration of zinc than the other lichens (Bajpai et al. 2011).

Similarly, in the present findings, maximum accumulation of $\mathrm{Pb}\left(11.25 \pm 0.15 \mu \mathrm{g} \mathrm{g}^{-1} \mathrm{dw}\right)$ and $\mathrm{Zn}\left(145.17 \pm 7.7 \mu \mathrm{g} \mathrm{g}^{-1} \mathrm{dw}\right)$ were found at site-4 (Fig 1), as these sites showed heavy vehicular activity/ emissions. Site 4 with higher vehicular activities exhibit maximum concentration of Zinc $\left(145.17 \pm 7.7 \mu \mathrm{g} \mathrm{g}^{-1}\right)$ followed by site $3\left(118.8 \pm 16.98 \mu \mathrm{g} \mathrm{g}^{-1}\right)$ which also have vehicular activities. Zinc chloride is a chemical which used in the manufacturing of tyres of motor vehicles, and this may be the reason for accumulation of zinc in the lichens as site 4 and site- 3 are the traffic rich areas than the other two sites.

According to Baptista et al. (2008), Iron (Fe) content in lichens is evidently affected by iron originating from fuel and soil dust. Lichens have special affinity with iron, and most of the lichens accumulate the metal in higher concentration than other metals. Majority of the previous findings carried out in Indian lichens, regarding metal accumulation, exhibited higher concentration of Fe (Nayaka et al. 2003, Shukla et al. 2007). Pyxine cocoes accumulates higher amount of iron ranging from 1573.0-19374.0 $\mu \mathrm{g} \mathrm{g}^{-1}$ (Saxena et al. 2007). Similarly, in the present study, iron was accumulated in higher concentrations at all the sites especially at site 2 , it was $1018.46 \pm 65.23 \mu \mathrm{g} \mathrm{g}^{-}$ ${ }^{1} \mathrm{dw}$.

Furthermore, the concentration of $\mathrm{Al}, \mathrm{Cd}, \mathrm{Co}, \mathrm{Cu}, \mathrm{Fe}, \mathrm{Hg}, \mathrm{Mg}$ and $\mathrm{Mn}$ was recorded maximum at the site 2 in comparison to the other three sites. Higher accumulation of most of the metals may be because of the presence of more than fifty industries; emitting various types of contaminants into the atmosphere. Moreover, the metals in lichens exhibit a sequence of $\mathrm{Fe}>\mathrm{Cr}>\mathrm{Al}>\mathrm{Mg}>\mathrm{Zn}>\mathrm{Mn}>\mathrm{Cu}>\mathrm{Cd}>\mathrm{Ni}>\mathrm{Pb}$. 


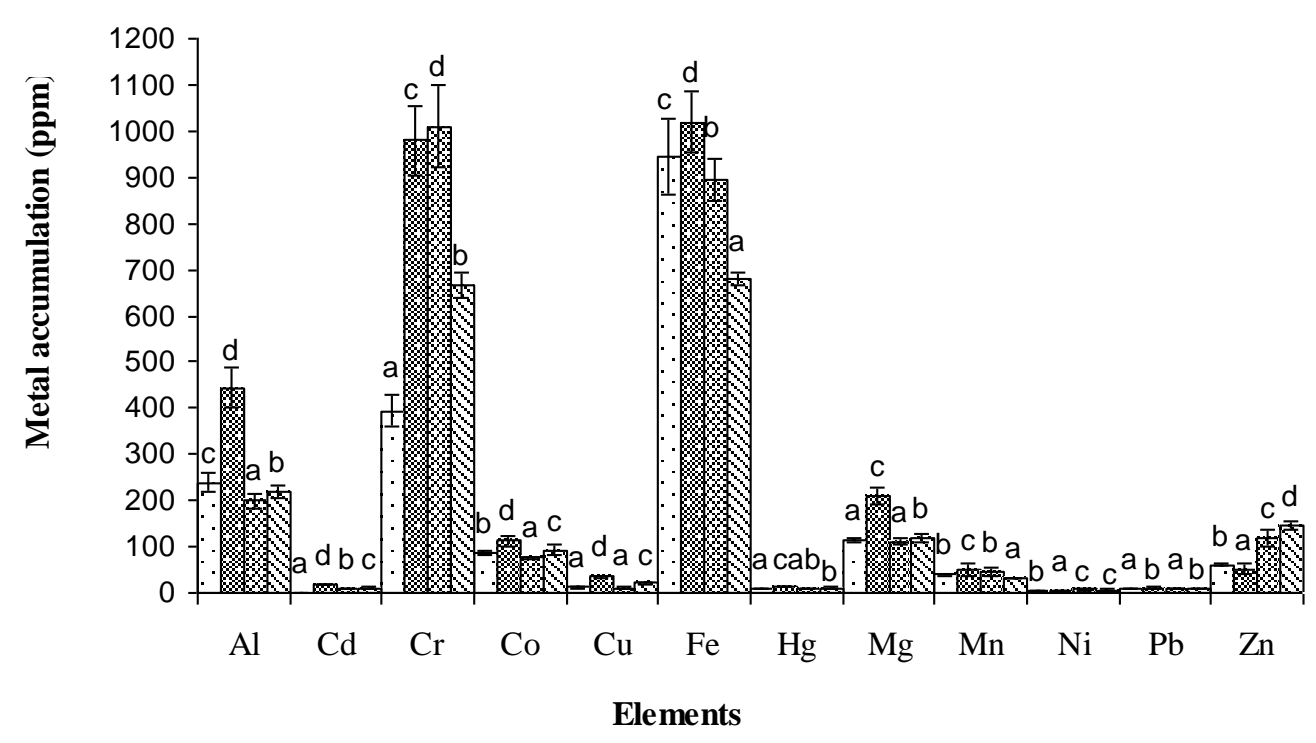

Fig. 2 - Metal accumulation at different sites

Table 3 Metal accumulation at different sites

\begin{tabular}{llllll}
\hline $\begin{array}{l}\text { S. } \\
\text { No. }\end{array}$ & Metals & \multicolumn{3}{l}{ Values (PPM) } & \\
\hline & & Site 1 & Site 2 & Site 3 & Site 4 \\
1 & $\mathrm{Al}$ & $239.45 \pm 21 \mathrm{c}$ & $443.2 \pm 12.85 \mathrm{~d}$ & $198.98 \pm 10.64 \mathrm{a}$ & $219.76 \pm 7.25 \mathrm{~b}$ \\
2 & $\mathrm{Cd}$ & $1.14 \pm 0.08 \mathrm{a}$ & $17.74 \pm 1.64 \mathrm{~b}$ & $7.63 \pm 0.74 \mathrm{~d}$ & $11.2 \pm 1.26 \mathrm{c}$ \\
3 & $\mathrm{Cr}$ & $392.82 \pm 3.58 \mathrm{a}$ & $979.92 \pm 14.56 \mathrm{c}$ & $1009.89 \pm 12.64 \mathrm{~d}$ & $668.27 \pm 7.4 \mathrm{~b}$ \\
4 & $\mathrm{Co}$ & $87.78 \pm 5.4 \mathrm{~b}$ & $112.53 \pm 11.24 \mathrm{~d}$ & $76.66 \pm 7.17 \mathrm{a}$ & $93.47 \pm 9.37 \mathrm{c}$ \\
5 & $\mathrm{Cu}$ & $11.8 \pm 0.85 \mathrm{a}$ & $34.84 \pm 2.5 \mathrm{~d}$ & $11.2 \pm 2.4 \mathrm{a}$ & $21.65 \pm 1.49 \mathrm{c}$ \\
6 & $\mathrm{Fe}$ & $944.47 \pm 8.12 \mathrm{c}$ & $1018.46 \pm 16.23 \mathrm{~d}$ & $895.17 \pm 11.21 \mathrm{~b}$ & $678.54 \pm 14.55 \mathrm{a}$ \\
7 & $\mathrm{Hg}$ & $8.29 \pm 0.95 \mathrm{a}$ & $14.08 \pm 1.54 \mathrm{c}$ & $9.43 \pm 0.91 \mathrm{ab}$ & $10.96 \pm 1.2 \mathrm{~b}$ \\
8 & $\mathrm{Mg}$ & $113.19 \pm 5.74 \mathrm{a}$ & $210.36 \pm 19 \mathrm{c}$ & $110.96 \pm 8.21 \mathrm{a}$ & $119.5 \pm 9.1 \mathrm{~b}$ \\
9 & $\mathrm{Mn}$ & $40.11 \pm 3.1 \mathrm{~b}$ & $49.99 \pm 12.4 \mathrm{c}$ & $44.52 \pm 10 \mathrm{~b}$ & $32.6 \pm 0.05 \mathrm{a}$ \\
10 & $\mathrm{Ni}$ & $4.68 \pm 0.54 \mathrm{~b}$ & $3.31 \pm 0.061 \mathrm{a}$ & $7.36 \pm 0.87 \mathrm{c}$ & $6.64 \pm 0.5 \mathrm{c}$ \\
11 & $\mathrm{~Pb}$ & $8.4 \pm 0.45 \mathrm{a}$ & $10.55 \pm 0.92 \mathrm{~b}$ & $8.5 \pm 0.6 \mathrm{a}$ & $11.25 \pm 0.15 \mathrm{~b}$ \\
12 & $\mathrm{Zn}$ & $60.5 \pm 2.1 \mathrm{~b}$ & $50.88 \pm 11.5 \mathrm{a}$ & $118.8 \pm 16.98 \mathrm{c}$ & $145.17 \pm 7.7 \mathrm{~d}$ \\
\hline
\end{tabular}

One Way ANOVA

$\mathrm{p} \leq 0.05$

\section{Conclusion}

Since the lichens are excellent bioaccumulators of heavy metals, it is used in the biomonitoring studies as well as to detect the metallic and organic pollutants from the environment. Active monitoring studies have been carried out with different lichen species till date, but this is first study with Dirinaria applanata. Also clearly proved that D. applanata is a good accumulator compare with the other lichen species. Hence from the present study, it was concluded that the accumulation of heavy metals in the transplanted lichen thallus indicates that Cuddalore city has been highly contaminated with the heavy metals and the levels were above the EPA standards. The higher accumulation of $\mathrm{Cr}, \mathrm{Cd}, \mathrm{Ni}$ and $\mathrm{Pb}$ indicates the hazardous status of the study area. Moreover, it is an alarming situation that warrants the need for some safety measures to avoid the environmental pollution. 


\section{Acknowledgements}

The authors are thankful to Prof. K. Kathiresan, Dean \& Director, CAS in Marine Biology, Annamalai University for the help during sample collection in Pichavaram mangroves and Centralized Instrumentation Facility, CASMB, AU for the analyses of heavy metals. Besides, Dr. R. Anburaj \& Mr. A. Sathishkumar, CASMB, AU are deeply acknowledged for rendering help during the collection and transplantation of lichens.

\section{References}

Awasthi DD. 2007 - A compendium of the Macrolichens from India, Nepal and Sri Lanka. Bishen Singh Mahendra Pal Singh, Dehra Dun, India. 580 pp.

Bajpai R, Upreti DK, Mishra SK. 2004 - Pollution monitoring with the help of lichen transplant technique at some residential sites of Lucknow city, Uttar Pradesh. Journal of Environmental Biology 25(2), 191-195.

Bajpai R, Upreti DK, Dwivedi SK. 2010 - Passive monitoring of atmospheric heavy metals in a historical city of central India by Lepraria lobificans Nyl. Environmental Monitoring and Assessment 166, 477-484.

Bajpai R, Upreti DK, Nayaka S. 2010a - Accumulation of Arsenic and Fluoride in Lichen Pyxine cocoes (Sw.) Nyl.,Growing in the Vicinity of Coal-based Thermal Power Plant at Raebareli, Indian Journal of Experimental Sciences 1(4) 37-40.

Bajpai R, Upreti DK, Nayaka S, Kumari B. 2010b - Biodiversity, bioaccumulation and physiological changes in lichens growing in the vicinity of coal-based thermal power plant of Raebareli district, North India. Journal of Hazardous Materials 174, 429-436.

Bajpai R and Upreti DK. 2012 - Accumulation and toxic effect of arsenic and other heavy metals in a contaminated area of West Bengal, India, in the lichen Pyxine cocoes ( $\mathrm{Sw}$.) Nyl. Ecotoxicology and Environmental Safety 83, 63-70.

Bajpai R, Upreti DK, Dwivedi SK. 2009 - Arsenic accumulation in lichens of Mandav monuments, Dhar district, Madhya Pradesh, India. Environmental Monitoring and Assessment 159, 437 442.

Bajpai R, Mishra GK, Mohabe S, Upreti DK, Nayaka S. 2011 - Determination of atmospheric heavy metals using two lichen species in Katni and Rewa cities, Indian Journal of Environmental Biology 32, 195-199.

Baptista MS, Teresa M, Vasconcelos SD, Carbral JP, Freitas CM, Pacheo AMG. 2008 - Copper, nickel, lead in lichens and tree bark transplants over different period of time. Environmental Pollution 151, 408-413.

Brodo IM. 1961 - Transplant experiment with corticolous lichens using a new technique. Ecologia., 45, 838-841.

Dubey AN, Pandey V, Upreti DK, Singh J. 1999 - Accumulation of Pb by lichen growing in and around Faizabad city. Journal of Environmental Biology. 20(3), 223-225.

Lantzy RJ and Mackenzie FT. 1979 - Atmospheric trace metals: Global cycles and assessment of man's impact. Geochimica et Cosmochimica Acta 43(4), 511-525

Le Blanc F and Rao DN. 1973 - Effect of SO2 on lichens and mosses transplant. Ecologia, 54, 612-614.

Lide DR. 2005 - CRC Handbook of Chemistry and Physics, 86th Ed., Boca Raton, FL, CRC Press

Mishra SK, Upreti DK, Pandey V, Bajpai R. 2003 - Pollution monitoring with the help of lichen transplant technique in some commercial and industrial areas of Lucknow city. Pollution Research 22(2), 221-225.

Morrow H. 2010. - "Cadmium and Cadmium Alloys." Kirk-Othmer Encyclopedia of Chemical Technology. John Wiley \& Sons. pp. 1-36.

Nayaka S, Upreti DK, Gadgil M, Pandey V. 2003 - Distribution pattern and heavy metal accumulation in lichens of Bangalore City with special reference to Lalbagh Garden. Current Science 84, 674-680. 
Rani M, Shukla V, Upreti DK, Rajwar GS. 2011. Periodical monitoring with lichen, Phaeophyscia hispidula (Ach.) Moberg in Dehradun city, Uttarakhand, India. Environmentalist 31, 376381.

Satya, Upreti DK. 2009 - Correlation among carbon, nitrogen, sulphur and physiological parameters of Rinodina sophodes found at Kanpur city, India. Journal of Hazardous Materials 169, 1088-1092.

Saxena S, Upreti DK, Sharma N. 2007 - Heavy metal accumulation in lichens growing in north side of Lucknow City, India. Journal of Environmental Biology 28(1), 49-51.

Shtiza A, Swennen R, Tashko A. 2008 - Chromium speciation and existing natural attenuation conditionsin lagoonal and pond sediments in the former chemical plant of Porto-Romano (Albania). Environmental Geology 53, 1107-1128

Schutte JA. 1977 - Chromium in two corticolous lichens from Ohio and West Virginia. Brylogist 80, 279-283.

Shukla V and Upreti DK. 2007 - Heavy Metal Accumulation in Phaeophyscia hispidula En Route to Badrinath, Uttaranchal, India. Environmental Monitoring and Assessment 131, 365-369.

Shukla V, Upreti DK, Patel DK, Tripathi R. 2010 - Accumulation of Polycyclic Aromatic Hydrocarbons in some lichens of Garhwal Himalayas, India. International Journal of Environment and Waste Management 5(1/2), 104-113.

Shukla V and Upreti DK. 2011 - Changing lichen diversity in and around urban settlements of Garhwal Himalayas due to increasing anthropogenic activities. Environmental Monitoring and Assessment 174, 439-444.

Singh KP and Sinha GP. 2010 - Indian Lichens - An annotated checklist. Botanical Survey of India, Ministry of Environment and Forests, Govt. of India. $571 \mathrm{pp}$.

Takala K and Okkonen H. 1981 - Lead content of an epiphytic lichen in the urban area of Kuopio, East Central Finland. Annales Botanici Fennici 18, 85-89.

Upreti DK and Pandey V. 1994 - Heavy metal content of Antarctic lichen Umbilicaria. Feddes Repertorium, 105, 197-199.

Upreti DK and Pandey V. 2000 - Determination of heavy metals in lichens growing on different ecological habitats in Schirmacher Oasis, East Antarctica. Spectroscopy Letters 33(3), 435444.

Upreti DK and Bajpai A. 2001 - Pollution monitoring with the help of lichen transplant technique in Lucknow city. In $2^{\text {nd }}$ International Conference on Plants and Environmental Pollution (ICPEP-2), NBRI, Lucknow (Abstract). 97 pp.

Walting RJ and Walting HR. 1982 - Metal surveys in South African Estuaries: Swartkops River. Water SA 8(1), 26-35. 